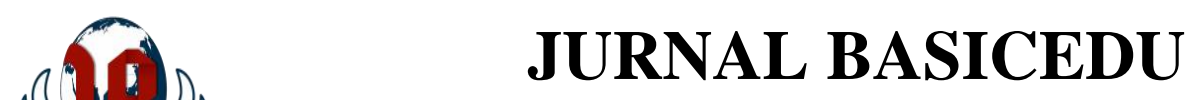

Volume 5 Nomor 4 Tahun 2021 Halaman 1754 - 1765

Research \& Learning in Elementary Education

https://jbasic.org/index.php/basicedu

PAHLAWAN

\title{
Pengembangan Bahan Ajar Klasifikasi Materi Terintegrasi Matematika Berbasis Masalah untuk Meningkatkan Kemampuan Berfikir Kritis Mahasiswa PGSD
}

\author{
Indriani Sevti Annisa ${ }^{1 凶}$, Yanti Fitria ${ }^{2}$ \\ Pendidikan Dasar, Pascasarjana Universitas Negeri Padang, Indonesia ${ }^{1,2}$ \\ E-mail: indrianisevti@gmail.com ${ }^{1}$, yanti_fitria@ fip.unp.ac.id ${ }^{2}$
}

\begin{abstract}
Abstrak
Tujuan penelitian ini untuk peningkatan kemampuan berpikir kritis (KBK) mahasiswa PGSD melalui hasil pengembangan bahan ajar berorientasi masalah yang valid, praktis, dan efektif. Metode penelitian yang digunakan merupakan model ADDIE meliputi: analysis, design, development, implementation, dan evaluation. Bahan ajar yang dikembangkan dianalisis oleh tim ahli. Subjek penelitian yaitu mahasiswa semester 3. Praktisnya bahan ajar dilihat dari keterlaksanaan SAP, angket tanggapan mahasiswa, dan dosen. Keefektifan bahan ajar dilihat dari penilaian proses, pengamatan, dan tes.Hasil penelitian validasi yang diperoleh terhadap RPS, SAP, bahan ajar dan soal tes dengan rerata $85 \%, 91 \%, 87 \%$, dan $89 \%$ kategori sangat valid. Hasil uji praktikalitas dilihat dari keterlaksanaan SAP, respon mahasiswa dan dosen dengan rerata $81 \%, 81 \%$, dan $89 \%$ kategori praktis. Hasil penilaian proses kemampuan berpikir kritis mahasiswa wilayah AT dengan rerata $82 \%$ dan wilayah BB $82 \%$. Pengamatan aktivitas berpikir kritis LPTK wilayah AT dan BB yaitu $80 \%$ dan $82 \%$, dan tes kemampuan berpikir kritis dengan $\mathrm{N}$-gain LPTK wilayah AT 0,50 dan wilayah BB 0,59 yang terlihat efektif dalam peningkatan KBK.
\end{abstract}

Kata Kunci: Bahan Ajar, Klasifikasi Materi Terintegrasi Matematika,Kemampuan Berpikir Kritis.

\begin{abstract}
The purpose of this study to improve the critical thinking skills of PGSD students through the development of valid, practical, and effective problem-oriented teaching materials. The research method used the ADDIE model including analysis, design, development, implementation, and evaluation. The teaching materials developed were analyzed by a team of experts. The research subjects are 3rd-semester students. Practical teaching materials are seen from the implementation of SAP, student response questionnaires, and lecturers. The effectiveness of teaching materials is seen from the process assessment, observation, and tests. The results of the validation research obtained for the RPS, SAP, teaching materials, and test questions with an average of $85 \%, 91 \%, 87 \%$, and $89 \%$ very valid categories. Results of the practicality test were seen from the implementation of SAP, the responses of students and lecturers with an average of $81 \%$, $81 \%$, and $89 \%$ practical categories. Results the assessment of the critical thinking ability students in the AT region with an average of $82 \%$ and the BB region $82 \%$. Observations critical thinking activities of LPTKs in AT and BB areas are $80 \%$ and $82 \%$, and critical thinking skills tests with $N$-gain LPTKs in AT areas 0.50, BB areas 0.59 which look effective in improving $K B K$.
\end{abstract}

Keywords: teaching materials, integrated material classification Mathematics, Critical Thinking Skills.

Copyright (c) 2021 Indriani Sevti Annisa, Yanti Fitria

Corresponding author :

Email : indrianisevti@gmail.com

DOI : https://doi.org/10.31004/basicedu.v5i4.1019

ISSN 2580-3735 (Media Cetak)

ISSN 2580-1147 (Media Online)

Jurnal Basicedu Vol 5 No 4 Tahun 2021 p-ISSN 2580-3735 e-ISSN 2580-1147 
1755 Pengembangan Bahan Ajar Klasifikasi Materi Terintegrasi Matematika Berbasis Masalah untuk Meningkatkan Kemampuan Berfikir Kritis Mahasiswa PGSD- Indriani Sefti Annisa, Yanti Fitria

DOI : https://doi.org/10.31004/basicedu.v5i4.1019

\section{PENDAHULUAN}

Perkembangan ilmu pengetahuan dan teknologi menuntut mahasiswa sebagai calon pendidik untuk dapat mengembangkan keterampilan dan kemampuannya agar tujuan pendidikan dapat tercapai secara optimal (Pendidikan, 2016). Salah satunya mahasiswa diharapkan mampu mengintegrasikan antara satu ilmu dengan ilmu lainnya (Kiray, 2011). Upaya ini dilakukan agar keterampilan dan kemampuan berpikir kritis mahasiswa terhadap dua disiplin ilmu tersebut dapat berkembang sesuai tuntutan zaman. Pada dasarnya sains dan Matematika tidak dapat dipisahkan satu sama lain (Kurt \& Pehlivan, 2013). Sains merupakan mitra logis matematika untuk mengintegrasikan suatu konten sehingga mampu mengintegrasikan sains dengan matematika (Treacy \& Donoghue, 2014).

Pengintegrasian sains dan matematika bermanfaat untuk pembelajaran dan pemahaman siswa, dapat memfasilitasi pengembangan motivasi, keterlibatan, keterampilan pemecahan masalah, kekritisan, dan relevansi konsep yang dipelajari (Ríordáin et al., 2016). Sehingga dengan mengimplementasikan pembelajaran sains terintegrasi matematika dapat meningkatkan pemahaman yang lebih dalam sikap dan faktor- faktor yang mempengaruhi dalam memajukan pelaksanaan pendidikan yang lebih baik lagi (Thibaut et al., 2019). Pada dasarnya dalam kegiatan pembelajaran pemilihan model yang tepat perlu dilakukan agar pelaksanaanya sesuai dengan harapan dan dapat meningkatkan keterampilan berpikir kritis (Evi \& Indarini, 2021). Namun, kenyataannya penyelesaian permasalahan yang berkaitan dengan IPA belum mampu diselesaikan oleh mahasiswa (Y. Fitria et al., 2018). Hal ini berkaitan dengan kemampuan berpikir kritis mahasiswa belum optimal (Y. Fitria et al., 2019). Berdasarkan hasil observasi yang telah dilakukan ada beberapa hal yang menyebabkan kemampuan berpikir kritis mahasiswa yang belum optimal yaitu: (1) Pada saat dosen memberikan pertanyaan tentang hubungan antara materi dengan kehidupan sehari-hari, mahasiswa belum mampu menjawab dan menentukan keterkaitan antara keduanya, (2) Dalam menyimpulkan materi, terlihat mahasiswa kesulitan dalam memberikan pendapatnya, (3) Saat diberikan sebuah permasalahan, mahasiswa mengalami kesulitan untuk menjelaskan sebab dan akibatnya. Selain itu mahasiswa tidak memiliki buku pegangan dalam melaksanakan perkuliahan. Perkuliahan yang dilakukan hanya berupa diskusi kelompok dengan setiap kelompok membahas satu topik untuk dipresentasikan. Selanjutnya, terdapatnya perbedaan kurikulum di SD dengan Kurikulum di PGSD sehingga pengalaman belajar terintegrasi yang dimiliki oleh mahasiswa belum maksimal, bahan ajar sains yang digunakan masih belum terintegrasi matematika, pembelajaran yang dilakukan masih terkotak-kotak sementara di lapangan guru mengajarkan secara terintegrasi.

Sebagai mahasiswa calon pendidik dalam pembelajaran sangat penting memanfaatkan sains terintegrasi matematika (Yanti Fitria et al., 2018). Dampak positifnya dapat mengembangkan kemampuan dan keterampilan mahasiswa dalam kedua disiplin ilmu tersebut secara terintegrasi. Sehingga pola pikir mahasiswa sudah terlatih dalam mengintegrasikan dua disiplin ilmu tersebut. Nantinya diharapkan mahasiswa sebagai calon pendidik lebih mudah mengaplikasikan dua disiplin ilmu yang terintegrasi dan memiliki pengalaman yang lebih luas. Sains terintegrasi matematika penting dipelajari mahasiswa agar dapat memiliki kemampuan dalam menganalisa asumsi yang logis sebagai acuan agar dapat menarik sebuah kesimpulan (Yanti Fitria, 2014). Dalam melakukannya dibutuhkan kemampuan berpikir kritis sebagai perwujudan kemampuan berpikir tingkat tinggi agar memiliki pemahaman yang baik terhadap konsep yang dipelajari sehingga mampu menarik kesimpulan.

Pada dasarnya bahan ajar dapat digunakan untuk mendukung proses pembelajaran. Bahan ajar ini digunakan pendidik dalam pelaksanaan kegiatan pembelajaran di kelas (Zuryanty et al., 2019) . Bahan ajar hendaknya sesuai dengan tujuan yang ingin dicapai. Selain penggunaan bahan ajar pemilihan model pembelajaran juga dapat menunjang kegiatan belajar (Pranaja \& Astuti, 2019). Bahan yang dimaksud bisa berupa bahan tertulis maupun bahan tidak tertulis. Penggunaan bahan ajar yang dikembangkan hendaknya 
1756 Pengembangan Bahan Ajar Klasifikasi Materi Terintegrasi Matematika Berbasis Masalah untuk Meningkatkan Kemampuan Berfikir Kritis Mahasiswa PGSD- Indriani Sefti Annisa, Yanti Fitria

DOI : https://doi.org/10.31004/basicedu.v5i4.1019

sesuai dengan tujuan yang ingin dicapai. Penggunaan model pembelajaran berbasis masalah salah satunya. Model ini merupakan sebuah model yang dapat mengembangkan kemampuan mahasiswa dalam memecahkan permasalahan yang dihadapinya dalam kehidupan sehari-hari sehingga dapat merangsang untuk belajar (Kurinasih, 2014). Tergambar bahwa pembelajaran berbasis masalah merupakan suatu model yang menggunakan masalah kontekstual sebagai awal dari proses yang bisa melatih siswa dalam pemecahan masalah yang dialaminya dalam kehidupan sehari-hari (Yanti Fitria, 2019). Berdasarkan permasalahan di atas maka perlu dikembangkan bahan ajar yang sesuai dengan karakteristik mahasiswa, menarik, praktis dan efektif digunakan. Salah satu solusinya adalah dengan mengembangkan bahan ajar klasifikasi materi terintegrasi matematika berbasis masalah. Bahan ajar ini dikembangkan dengan mengutamakan konten materi dan latihan berbasis masalah agar dapat memfasilitasi mahasiswa dalam proses pembelajaran yang aktif.

\section{METODE PENELITIAN}

Penelitian ini adalah penelitian pengembangan dengan tujuan menghasilkan dan mengembangkan produk baru (Sugiyono, 2012). Pengembangan produk merupakan bahan ajar berbentuk modul. Model pengembangan dalam penelitian mengacu pada model ADDIE yang terdiri dari lima fase yaitu analysis, design, develop, implement, dan evaluate. Model ini merupakan pendekatan yang membantu peneliti mengembangkan konten apapun, atau untuk membuat desain yang efisien untuk guru (Aldoobie, 2015).

Prosedur pengembangan pada bahan ajar disesuaikan dengan tahapan model ADDIE. Adapun pada tahapan analyze dilakukan validasi ketidakseimbangan antara harapan dan kenyataan dengan melakukan pengamatan di lapangan dan kondisi ideal yang diharapkan serta penyebab terjadinya (Dousay \& Logan, 2011). Melakukan penyebaran angket analisis kebutuhan mengakomodasi permasalahan yang ada di lapangan. Menentukan tujuan pengembangan untuk menemukan solusi dan menyelesaikan permasalahan yang ditemukan (Branch, 2010). Melakukan konfirmasi sasaran pengembangan dengan mengidentifikasi karakteristik dan kebutuhan dari subjek yang terlibat. Mengidentifikasi hal-hal yang dibutuhkan dalam pengembangan, melakukan analisis bentuk produk yang akan dikembangkan, dan menyusun rencana pelaksanaan pengembangan.

Pada tahapan design bertujuan untuk mengkonfirmasi tujuan yang diharapkan dan tata cara pengujian yang sesuai dengan menyusun daftar komponen yang dibutuhkan dalam produk, menyusun tujuan pengembangan produk, merancang instrumen validasi dan uji coba produk, dan memprediksi pengeluaran dalam pembuatan produk. Pada tahapan develop bertujuan untuk menghasilkan bahan ajar yang valid, praktis, dan efektif. Hal- hal yang akan dilakukan yaitu membuat produk sesuai dengan rancangan, memilih atau mengembangkan media pendukung, mengembangkan petunjuk penggunaan bagi mahasiswa dan pendidik, melakukan perbaikan terhadap produk sebelum diterapkan dalam pembelajaran, dan melakukan uji coba pendahuluan. Pada tahapan implement dilakukan penyiapan kondisi belajar untuk menerapkan produk yang dikembangkan sebahai sumber belajar dan proses pembelajaran. pada tahapan evaluate bertujuan untuk mengetahui kualitas dari produk. Tahapan ini berkaitan dengan hasil validasi dan kepraktisan dari produk yang dihasilkan dikumpulkan, dianalisa, dan disimpulkan.

Penelitian ini dilaksanakan pada mahasiswa semester 3 PGSD. Subjek uji coba pengembangan bahan ajar sains terintegrasi matematika pada materi klasifikasi materi dan perubahannya adalah mahasiswa yang mengambil mata kuliah konsep dasar IPA 3. Pengambilan data dalam Penelitian ini berupa data primer. Pertama hasil validasi bahan ajar oleh pakar. Kedua diperoleh dari pelaksanaan uji coba. Data yang diambil pada uji coba ini berupa: (1) hasil pengamatan pelaksanaan bahan ajar dari observer, (2) hasil tanggapan dosen terhadap penggunaan bahan ajar, (3) tanggapan mahasiswa setelah uji coba bahan ajar dan hasil pembelajaran mahasiswa. Intrumen pengumpulan data yang digunakan yaitu (1) instrumen validasi bahan ajar, (2) instrumen kepraktisan bahan ajar, dan (3) instrumen keefektifan bahan ajar. Teknik analisis data yang 
1757 Pengembangan Bahan Ajar Klasifikasi Materi Terintegrasi Matematika Berbasis Masalah untuk Meningkatkan Kemampuan Berfikir Kritis Mahasiswa PGSD- Indriani Sefti Annisa, Yanti Fitria

DOI : https://doi.org/10.31004/basicedu.v5i4.1019

digunakan adalah analisis data deskriptif, yaitu mendeskripsikan tingkat validitas bahan ajar, kepraktisan bahan ajar, dan efektifitas bahan ajar.

\section{HASIL DAN PEMBAHASAN}

Tahap Analyze (menganalisis) terdiri dari dua bagian yang meliputi analisis dokumen dan analisis kebutuhan. Pada tahapan analisis dokumen yang dilakukan dengan menganalisis kurikulum dan menelaah muatan RPS konsep dasar IPA 3 dan dasar-dasar matematika SD yang diperlukan untuk mempelajari pencapaian pembelajaran, pengalaman belajar, dan memilih strategi yang sesuai dengan pengembangan bahan ajar. Hasil analisis dijabarkan dalam pencapaian dan pengalaman belajar yang menjadi pertimbangan dalam menentukan konsep dan menyusun bahan ajar yang didasarkan pada langkah pembelajaran berbasis masalah dalam peningkatan kemampuan berpikir kritis mahasiswa. Sedangkan pada tahapan analisis kebutuhan dilihat dari dua sudut pandang yaitu dosen dan mahasiswa. Hasil yang didapat bahwasanya bahan ajar yang mengintegrasikan sains dan matematika berbasis masalah dengan desain yang menarik dan kualitas baik dapat merangsang mahasiswa untuk berpikir kritis. Selanjutnya, bahan ajar sains terintegrasi matematika berbasis masalah yang didesain ini dapat memudahkan mahasiswa dalam menerima pembelajaran.

Tahap Design (merancang) Rencana Pembelajaran Semester (RPS) sains terintegrasi matematika berbasis masalah pada mahasiswa semester 3. Rencana Pembelajaran yang dikembangkan memaparkan tahapan pembelajaran sains terintegrasi matematika yang dikombinasikan dengan langkah pembelajaran berbasis masalah. Karakteristik dari rancangan RPS ini dibuat lebih rinci dan mudah dipahami, serta dapat membantu proses pembelajaran sains terintegrasi matematika pada mahasiswa.

Satuan Acara Pembelejaran (SAP) secara lengkap dan sistematis dengan berpedoman pada RPS yang telah dikembangkan. Berdasarkan analisis materi sains terintegrasi matematika dapat dijabarkan capaian belajar dan pengalaman belajar mahasiswa dilaksanakan dalam 2 pembelajaran dengan waktu 2 x 50 menit. Pembelajaran dilaksanakan secara terstruktur melalui langkah-langkah pembelajaran berbasis masalah.

Pengembangan bahan ajar dapat memudahkan dosen dalam menyampaikan pembelajaran dan membantu mahasiswa dalam peningkatan KBK. Bahan ajar yang dirancang menggunakan model pembelajaran berbasis masalah serta disesuaikan dengan materi, capaian pembelajaran dan pengalaman belajar mahasiswa. Spesifikasi bahan ajar yang dikembangkan, yaitu sebagai berikut: 1) Didesain dengan background berwarna biru muda, 2) Bahan ajar yang dibuat menggunakan Microsoft Word 2010, 3) Font yang digunakan yaitu Times New Roman, Britannic Bold, dan Comic Sans MS dengan ukuran 12, 14,16,18 dan 20. 4) Penyajian materi menggunakan langkah pembelajaran berbasis masalah, 5) Bahan ajar dilengkapi dengan beberapa latihan serta contoh. Hasil bahan ajar untuk lebih jelasnya dijabarkan sebagai berikut:

\section{Cover bahan ajar}

Cover bahan ajar didesain dengan background utama berwarna biru muda. Pada cover disajikan juga ikon gambar utama yang identik dengan materi sains dan matematika. Desain Cover bahan ajar yang dikembangkan dapat dilihat pada gambar 1 . 
1758 Pengembangan Bahan Ajar Klasifikasi Materi Terintegrasi Matematika Berbasis Masalah untuk Meningkatkan Kemampuan Berfikir Kritis Mahasiswa PGSD-Indriani Sefti Annisa, Yanti Fitria DOI : https://doi.org/10.31004/basicedu.v5i4.1019

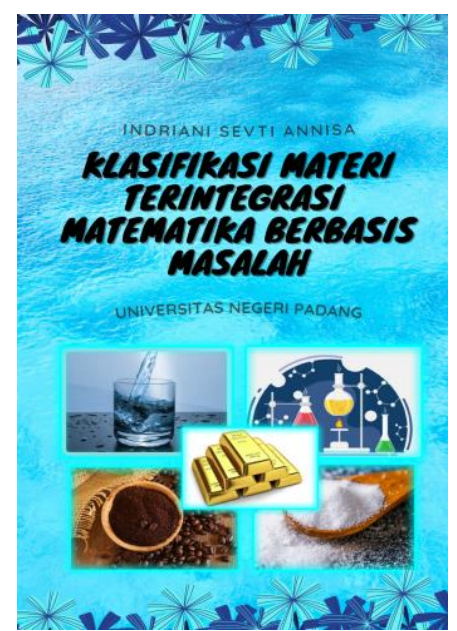

\section{Kata pengantar}

Gambar 1. Cover Bahan Ajar

Ucapan rasa syukur penulis tuliskan dalam kata pengantar dibuat untuk mengkomunikasikan kepada dosen dan mahasiswa dalam pembuatan bahan ajar ini. Judul kata pengantar dibuat type Bold dengan jenis tulisan Britannic Bold ukuran 14, sementara isinya type standar dengan jenis tulisan Times New Roman ukuran 12. Desain kata pengantar bahan ajar dapat dilihat pada gambar 2.

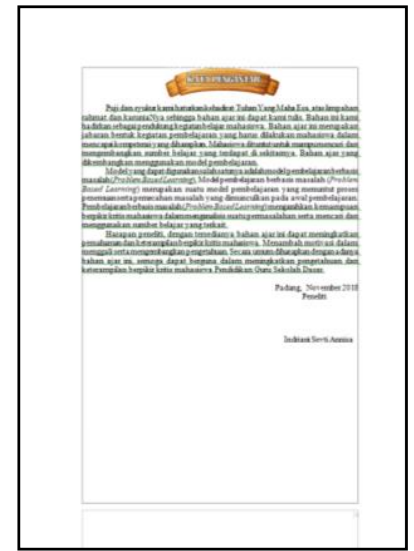

\section{Daftar isi}

Gambar 2. Kata Pengantar Bahan Ajar

Daftar isi dibuat untuk memudahkan mahasiswa dan dosen dalam menemukan halaman pada buku. Judul daftar isi dibuat dengan jenis tulisan Britannic Bold ukuran 14, sementara isinya type standar dengan jenis tulisan Times New Roman ukuran 12. Desain daftar isi bahan ajar dapat dilihat pada Gambar 3.

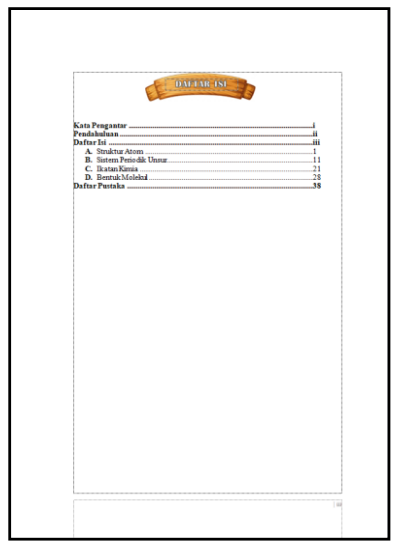

Gambar 3. Daftar Isi Bahan Ajar 
1759 Pengembangan Bahan Ajar Klasifikasi Materi Terintegrasi Matematika Berbasis Masalah untuk Meningkatkan Kemampuan Berfikir Kritis Mahasiswa PGSD- Indriani Sefti Annisa, Yanti Fitria

DOI : https://doi.org/10.31004/basicedu.v5i4.1019

\section{Materi atau informasi pendukung}

Bahan ajar yang dibuat dilengkapi dengan informasi pendukung berupa uraian materi tentang klasifikasi materi terintegasi matematika berbasis masalah. Materi atau informasi pendukung ini berfungsi untuk menambah pemahaman mahasiswa tentang klasifikasi materi terintegrasi matematika berbasis masalah. Uraian materi dapat dilihat pada gambar 4.

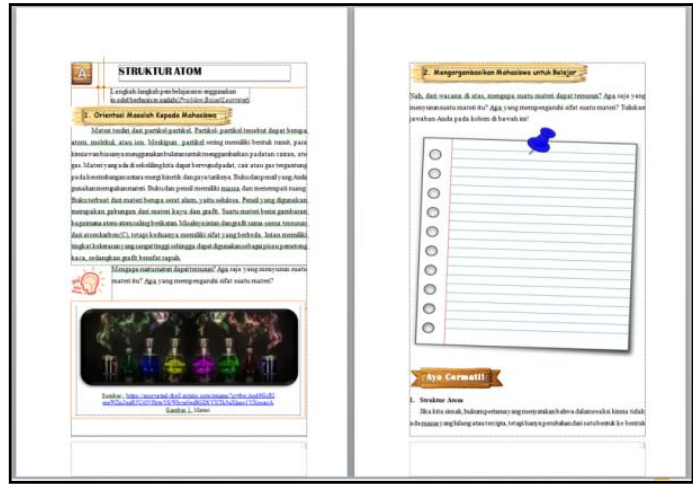

Gambar 4. Materi atau informasi pendukung bahan ajar

\section{Latihan}

Latihan yang terdapat dalam bahan ajar ini merupakan latihan untuk meningkatkan kemampuan mahasiswa dalam pembelajaran. Untuk lebih jelasnya dapat dilihat pada gambar 5.

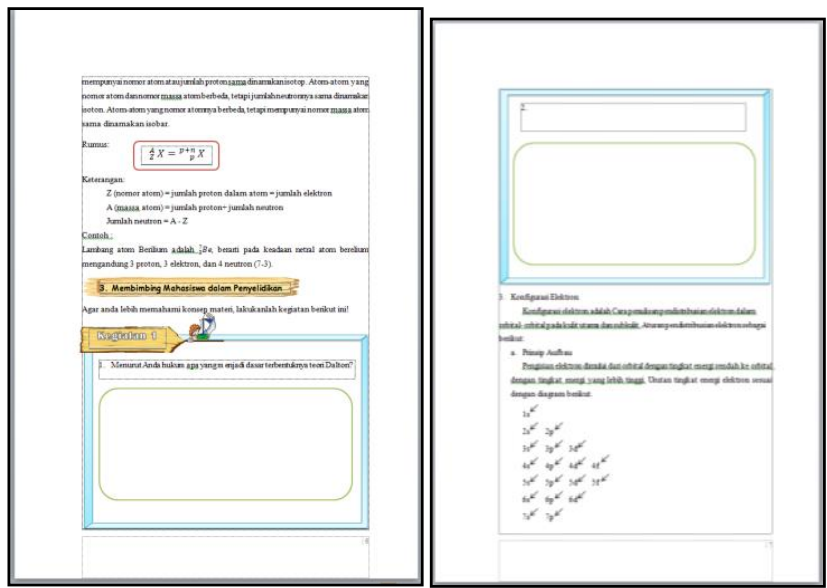

Gambar 5. Latihan

Tahap Develop (mengembangkan) dilakukan untuk memvalidasi RPS SAP, Bahan Ajar dan lembar Tes. Uji validitas dilakukan dengan mengkonnfirmasikan proses pembelajaran oleh para ahli dan praktisi diikuti dengan revisi dan perbaikan. Instrumen pengumpulan data validasi dapat dilihat pada tabel 1.

Tabel 1. Hasil penilaian instrumen oleh validator

\begin{tabular}{|c|l|c|c|}
\hline No & \multicolumn{1}{|c|}{ Instrumen } & Rata-rata & Kategori \\
\hline 1 & RPS & $86 \%$ & Sangat Valid \\
\hline 2 & SAP & $89 \%$ & Sangat Valid \\
\hline 3 & Bahan Ajar & $87 \%$ & Sangat Valid \\
\hline 4 & Soal Tes & $89 \%$ & Sangat Valid \\
\hline
\end{tabular}

Validasi RPS yang dilakukan pada beberapa aspek diantaranya merumuskan tujuan pembelajaran, menyajikan materi pembelajaran, langkah-langkah pembelajaran, pemilihan sumber pembelajaran, dan evaluasi. Hasil keseluruhan validasi RPS dari validator ahli $86 \%$ tergolong sangat valid. Validasi SAP dilakukan pada beberapa aspek diantaranya adalah identitas, perumusan tujuan, seleksi materi ajar, metode 
dan langkah- langkah pembelajaran, pemilihan sumber belajar, dan penilaian. Hasil keseluruhan validasi SAP dari validator ahli $89 \%$ termasuk dalam kategori sangat valid.

Validasi bahan ajar menitikberatkan pada beberapa aspek diantaranya kelayakan isi, bahasa, dan kegrafikan. Hasil keseluruhan evaluasi materi pembelajaran dari validator ahli dan validator praktisi sebesar 87 termasuk dalam kategori sangat valid. Validasi soal tes kemampuan berpikir kritis difokuskan pada dua aspek yaitu kelayakan isi dan bahasa. Rata-rata keseluruhan nilai validasi bahan ajar oleh validator ahli $89 \%$ dengan kategori sangat valid.

Uji praktikalitas dilakukan dengan mengamati tingkat keterlaksanaan satuan acara pembelajaran (SAP), respon dosen dan respon mahasiswa tentang bahan ajar sains terintegrasi matematika berbasis masalah. Dokumen yang dianggap valid kemudian diuji untuk melihat tingkat kepraktisan dalam penggunaannya. Rekapitulasi hasil kepraktisan dapat dilihat pada tabel 2.

Tabel 2. Hasil Penilaian Praktikalitas

\begin{tabular}{|c|l|c|c|}
\hline No & \multicolumn{1}{|c|}{ Instrumen } & Rata-rata & Kategori \\
\hline 1 & Pengamatan Keterlaksanaan SAP & $81 \%$ & Sangat Praktis \\
\hline 2 & Respons Mahasiswa & $81 \%$ & Sangat Praktis \\
\hline 3 & Respon Dosen & $89 \%$ & Sangat Praktis \\
\hline
\end{tabular}

Pengamatan implementasi SAP difokuskan untuk melihat apakah proses pembelajaran dilakukan sesuai dengan SAP. Hasil observasi dengan rata-rata $81 \%$ kategori sangat praktis. Selanjutnya dilakukan penilaian terhadap respon mahasiswa untuk mengetahui pendapat mengenai tingkat kepraktisan pembelajaran. Tingkat kepraktisan bahan ajar menurut mahasiswa yaitu sebesar $81 \%$ dengan kategori praktis. Hasil ini menunjukkan bahwa mahasiswa merasa tingkat berpikir kritis meningkat dan merasa terbantu dalam memahami materi sains terintegrasi matematika.

Hasil yang didapatkan dari penyebaran angket terhadap dosen secara umum didapatkan hasil kepraktisan bahan ajar 89\% dengan kategori sangat praktis. Hal ini menunjukkan bahwa dosen menganggap bahan ajar sains terintegrasi matematika berbasis masalah yang dikembangkan mudah digunakan dalam pembelajaran serta dapat membantu dalam proses pembelajaran sains terintegrasi matematika berbasis masalah.

Uji keefektifan dokumen pembelajaran pada topik klasifikasi materi terintegrasi dengan matematika menggunakan model PBL yang terdiri dari aktivitas siswa. Aktivitas siswa diamati dengan menggunakan instrumen lembar observasi. Kegiatan siswa yang diamati adalah: mengamati dan mendengarkan penjelasan dosen, memperhatikan materi pembelajaran, melakukan kegiatan dalam materi pembelajaran, mengajukan pertanyaan, dan memberikan tanggapan. Hasil observasi tersebut dapat dilihat pada Tabel 3.

Tabel 3. Hasil Observasi Aktifitas Berpikir Kritis Mahasiswa

\begin{tabular}{|c|c|c|c|c|c|c|c|c|c|}
\hline \multirow{2}{*}{ No } & \multirow{2}{*}{ Pertemuan } & \multicolumn{7}{|c|}{$\begin{array}{c}\text { Rata- } \\
\text { rata }\end{array}$} & \multirow{2}{*}{ Kategori } \\
\cline { 3 - 9 } & & $\mathbf{1}$ & $\mathbf{2}$ & $\mathbf{3}$ & $\mathbf{4}$ & $\mathbf{5}$ & $\mathbf{6}$ & \\
\hline 1. & I & $82 \%$ & $78 \%$ & $80 \%$ & $76 \%$ & $80 \%$ & $80 \%$ & $79,3 \%$ & Efektif \\
\hline 2. & II & $80 \%$ & $82 \%$ & $82 \%$ & $82 \%$ & $80 \%$ & $84 \%$ & $81,7 \%$ & Sangat Efektif \\
\hline \multicolumn{8}{|c|}{ Rata-rata } & $\mathbf{8 0 , 4 \%}$ & Efektif \\
\hline
\end{tabular}

Keterangan: 1: Memberikan respon terhadap pertanyaan dosen

2: Melaporkan hasil observasi

3: Membuat solusi dari masalah yang ditemukan

4: $\quad$ Menarik kesimpulan sesuai fakta

5: $\quad$ Mengidentifikasi asumsi yang tidak jelas atau dinyatakan

6: Mereview hasil diskusi yang telah dilakukan 
1761 Pengembangan Bahan Ajar Klasifikasi Materi Terintegrasi Matematika Berbasis Masalah untuk Meningkatkan Kemampuan Berfikir Kritis Mahasiswa PGSD- Indriani Sefti Annisa, Yanti Fitria

DOI : https://doi.org/10.31004/basicedu.v5i4.1019

Tahap implementation (penerapan) pengamatan aktifitas berpikir kritis difokuskan dalam keterampilan mahasiswa pada saat pembelajaran. Hasil pengamatan tersebut dapat dilihat pada Tabel 4.

Tabel 4. Hasil Observasi Aktifitas Berpikir Kritis Mahasiswa Saat Implementasi

\begin{tabular}{|c|c|c|c|c|c|c|c|c|c|}
\hline \multirow{2}{*}{ No } & \multirow{2}{*}{ Pertemuan } & \multicolumn{6}{|c|}{ Aspek yang Diamati } & \multirow{2}{*}{$\begin{array}{c}\text { Rata- } \\
\text { rata }\end{array}$} & \multirow{2}{*}{ Kategori } \\
\hline & & 1 & 2 & 3 & 4 & 5 & 6 & & \\
\hline 1. & $\mathrm{I}$ & $81 \%$ & $81 \%$ & $81 \%$ & $84 \%$ & $81 \%$ & $81 \%$ & $81,5 \%$ & Sangat Efektif \\
\hline 2. & II & $81 \%$ & $78 \%$ & $81 \%$ & $88 \%$ & $81 \%$ & $88 \%$ & $82,8 \%$ & Sangat Efektif \\
\hline \multicolumn{8}{|c|}{ Rata-rata } & $82,2 \%$ & Sangat Efektif \\
\hline
\end{tabular}

Keterangan: 1: Memberikan respon terhadap pertanyaan dosen

2: $\quad$ Melaporkan hasil observasi

3: $\quad$ Membuat solusi dari masalah yang ditemukan

4: $\quad$ Menarik kesimpulan sesuai fakta

5: $\quad$ Mengidentifikasi asumsi yang tidak jelas atau dinyatakan

6: $\quad$ Mereview hasil diskusi yang telah dilakukan

Tahap Evaluate (Mengevaluasi) merupakan tahapan terakhir dari model pengembanggan ADDIE. Penilaian diperoleh berdasarkan hasil praktikalitas dan efektivitas bahan ajar yang dikembangkan. Berdasarkan hasil kegiatan Uji coba pada kelas AT dan evaluasi yang telah dijawab untuk penilaian proses kemampuan berpikir kritis Rerata kelas pre-test sebesar 77,8 lebih rendah dibandingkan rerata skor post-test sebesar 88,8 dengan rerata gain skor sebesar 0,50 kategori sedang. Sedangkan pada kelas uji coba pada kelas lainnya didapat rerata skor pre-test sebesar 72,3 lebih rendah dibandingkan rerata skor post-test sebesar 88,5, dengan rerata gain skor sebesar 0,59 kategori sedang Sehingga terdapat peningkatan kemampuan berpikir kritis setelah menggunakan bahan ajar sains terintegrasi matematika.

Pengembangan bahan ajar sains terintegrasi matematika berbasis masalah ini menggunakan model pengembangan ADDIE yang meliputi 3 tahapan, yaitu tahapan studi pendahuluan, tahapan uji coba, dan tahapan implementasi yang telah dilakukan dengan baik. Berikut paparan mengenai hasil penelitian yang telah dilakukan, diuraikan lebih lanjut terutama yang berkaitan dengan karakteristik bahan ajar, tanggapan mahasiswa dan capaian kemampuan berpikir kritis mahasiswa yang dikembangkan.

Validnya suatu produk jika sudah merefleksikan jiwa pengetahuan (state of the art knowledge), hal inilah yang dikatakan dengan validasi isi (content validiy). Komponen-komponen yang terdapat dalam produk haruslah konsisten satu sama lain. Oleh karena itu validasi yang dilakukan terhadap bahan ajar sains terintegrasi matematika berbasis masalah ini menekankan pada isi. Dalam penelitian yang dilakukan, validasi dirinci menjadi beberapa bagian yaitu validasi isi, bahasa, penyajian, dan kegrafikan. Validasi ini dilakukan oleh tiga orang pakar ahli yang sudah berpengalaman untuk menilai suatu produk baru yang dirancang, sehingga dapat diketahui kelemahan dan keunggulannya (Sugiyono, 2012). Hasil validasi dari pakar ini dikumpulkan kemudian dianalisis untuk dicari rata-rata dari masing-masing indikator dan aspek. Hasil validasi dipaparkan sebagai berikut:

\section{Validasi RPS}

Beberapa aspek yang dikemukakan oleh Permenristekdikti No 44 tahun 2015 pasal 12 dalam melakukan proses validasi paling sedikit memuat yaitu: nama program studi, nama dan kode mata kuliah, semester, sks, nama dosen pengampu; capaian pembelajaran; kemampuan akhir; bahan kajian; metode pembelajaran; waktu; pengalaman belajar mahasiswa; kriteria, indikator, dan bobot penilaian; dan daftar referensi yang digunakan. Berdasarkan hasil penilaian validator dapat ditarik kesimpulan bahwa RPS yang dikembangkan telah valid. Hal ini dapat dinilai dari perolehan hasil validasi dengan rata-rata $91 \%$ dengan kategori sangat valid. Hal ini berdasarkan adanya kesesuaian identitas RPS, pencapaian pembelajaran, 
1762 Pengembangan Bahan Ajar Klasifikasi Materi Terintegrasi Matematika Berbasis Masalah untuk Meningkatkan Kemampuan Berfikir Kritis Mahasiswa PGSD- Indriani Sefti Annisa, Yanti Fitria

DOI : https://doi.org/10.31004/basicedu.v5i4.1019

indikator, metode, waktu, pengalaman belajar, kriteria, bobot penilaian, dan daftar referensi. Selain itu kegiatan yang dilakukan pada RPS sesuai dengan kebutuhan mahasiswa.

\section{Validasi SAP}

Beberapa aspek yang perlu diperhatikan dalam proses validasi SAP yang sesuai dengan yaitu: identitas SAP, perumusan tujuan pembelajaran, pemilihan materi pembelajaran, metode dan langkah pembelajaran, pemilihan sumber belajar, dan penilaian (Mulyasa, 2009:222). Pengembangan SAP menggambarkan kesesuaian seluruh konsep, kegiatan dan komponen yang terkandung didalamnya. Hal ini dapat dilihat dari hasil analisis validasi SAP dengan rata-rata 91\% kategori sangat valid. Sesuai dengan indikator, tujuan, materi, model pembelajaran, langkah-langkah pembelajaran, media, sumber dan penilaian yang dirumuskan dan yang dilakukan. Secara umum telah menggambarkan komponen yang sesuai di dalam pembuatan SAP.

\section{Validasi Bahan Ajar}

Berdasarkan hasil validasi dari segi kelayakan isi, kebahasaan, dan kegrafikan bahan ajar memperoleh nilai rata-rata $86 \%$ dengan kategori sangat valid. Oleh sebab itu, dapat disimpulkan bahan ajar yang telah dibuat telah sesuai. Isi bahan ajar sesuai dengan klasifikasi materi yang terintegrasi matematika di semester III PGSD. Bahan ajar merupakan bahan atau materi yang disusn secara sistematis yang dapat digunakan dosen dan mahasiswa dalam proses pembelajaran dalam mencapai tujuan pembelajaran (Prastowo, 2013). Salah satu tujuan pengembangan bahan ajar yaitu untuk membantu dan memudahkan mahasiswa dalam mempelajari sesuatu (Hamdani, 2011).

Pemilihan untuk dapat mencapai kompetensi dasar telah terdapat dalam isi bahan ajar yang dibuat. Selain itu bahasa yang digunakan sederhana dan mudah dipahami. Ejaan yang digunakan juga tepat. Desain pengembangan bahan ajar yang digunakan ditampilkan dengan warna yang menarik sehingga dapat memotivasi mahasiswa dalam melaksanakan kegiatan pembelajaran dengan baik. Hasil validasi bahan ajar memperoleh nilai rata-rata $86 \%$ dengan kategori sangat valid. Hasil ini menggambarkan bahan ajar yang dikembangan telah valid dan dapat digunakan.

\section{Tanggapan mahasiswa terhadap bahan ajar}

Respon mahasiswa terhadap bahan ajar yang berkaitan dengan praktikalitas yaitu kemudahan penggunaan bahan ajar oleh mahasiswa. Praktikalitas ini juga dilihat dari respon dosen atau pengajar dalam menggunakan bahan ajar. Praktikalitas ini bersifat praktis, artinya mudah dilaksanakan, mudah pemeriksaannya, dan dilengkapi dengan petunjuk agar mudah dalam pemakaiannya (Arikunto, 2010). Praktikalitas yang diamati yaitu keterlaksanaan satuan acara perkuliahan, respon dosen dan mahasiswa terhadap praktikalitas bahan ajar. Praktikalitas bahan ajar sains terintegrasi matematika berbasis masalah untuk mahasiswa PGSD secara keseluruhan berada pada kategori sangat praktis. Hal ini dilihat dari hasil observasi pengamatan Satuan acara perkuliahan dengan rata-rata $81 \%$ sangat praktis, hasil respon dosen $89 \%$ dengan kategori sangat praktis, hasil respon mahasiswa $81 \%$ dengan kategori praktis. Hasil ini menggambarkan bahwa bahan ajar yang dikembangkan sangat praktis dan dapat membantu dalam pelaksanaan pembelajaran klasifikasi materi terintegrasi matematika untuk mahasiswa PGSD.

\section{Pencapaian Kemampuan Berpikir Kritis Mahasiswa Setelah Menggunakan bahan ajar}

Efektivitas pencapaian keterampilan mahasiswa dapat dilihat setelah penggunaan bahan ajar. Bahan ajar dapat dikatakan efektif jika membawa efek atau pengaruh positif terhadap capaian tujuan pembelajaran. Capaian kemampuan berpikir kritis mahasiswa dalam bahan ajar sains terintegrasi matematika berbasis masalah dapat dilihat melalui hasil penilaian proses, pengamatan, dan tes kemampuan berpikir kritis dinyatakan meningkat, maka bahan ajar sains terintegrasi matematika berbasis masalah sudah efektif digunakan dalam pembelajaran klasifikasi materi terintegrasi matematika di semester 3 jurusan PGSD. Pembelajaran sains terintegrasi matematika dapat meningkatkan kemampuan berpikir tingkat tinggi, salah satunya berpikir kritis (Stohlmann et al., 2012). Selain itu pembelajaran berbasis masalah juga dapat 
1763 Pengembangan Bahan Ajar Klasifikasi Materi Terintegrasi Matematika Berbasis Masalah untuk Meningkatkan Kemampuan Berfikir Kritis Mahasiswa PGSD- Indriani Sefti Annisa, Yanti Fitria

DOI : https://doi.org/10.31004/basicedu.v5i4.1019

meningkatkan keterampilan mahasiswa dalam mengelola sumber belajar dan mampu mengritisi isinya (kemampuan berpikir kritis) (Sumarni, 2013).

Hal yang tidak mudah diwujudkan dalam penelitian ini adalah mendapatkan hasil yang sempurna, meskipun bahan ajar telah dibuat sesuai prosedur dan model yang sesuai. Pada awalnya, mahasiswa kesulitan untuk memahami materi yang akan di belajarkan. Hal ini dikarenakan, setiap mahasiswa berasal dari berbagai jurusan sehingga merasa asing dengan materi yang diajarkan. Akan tetapi lambat laun mahasiswa mulai memahami dan mampu memanfaatkan waktu yang dimiliki dengan baik dan efektif. Selanjutnya, pada tahap implementasi dalam penelitian pengembangan, seharusnya dilakukan pada skala yang lebih besar. Namun karena keterbatasan peneliti dari segi waktu, tenaga, dan biaya, maka implementasi penelitian hanya dilakukan pada satu kelas.

Pembelajaran menggunakan bahan ajar sains terintegrasi matematika berbasis masalah membuat mahasiswa aktif dan termotivasi dalam melaksanakan sejumlah kegiatan yang terdapat dalam bahan ajar. Disamping, itu penggunaan bahan ajar sains terintegrasi matematika berbasis masalah ini telah memberikan pengalaman belajar yang menarik bagi mahasiswa. Tahapan pembelajaran yang terstruktur dan sistematis, disajikan dengan bahasa komunikatif dan tampilan yang menarik, telah memberikan pandangan bagi mahasiswa bahwa pembelajaran sains yang diintegrasikan dengan matematika adalah sesuatu hal yang menyenangkan. Dengan demikian, pembelajaran sains yang diintegrasikan dengan matematika menggunakan bahan ajar sains terintegrasi matematika berbasis masalah bukan lagi pembelajaran yang kurang menarik dan membosanan. Oleh karena itu, penggunaan bahan ajar sains terintegrasi matematika berbasis masalah sangat direkomendasikan dalam menciptakan suasana pembelajaran yang menarik, interaktif, dan berkualitas.

\section{KESIMPULAN}

Bahan ajar yang dikembangkan tentang klasifikasi materi terintegrasi matematika berbasis masalah telah diuji keefektifannya. Berdasarkan pengembangan, uji coba, dan implementasi yang telah dilakukan, dapat disimpulkan sebagai berikut: 1) Karakteristik bahan ajar klasifikasi materi terintegrasi matematika untuk mahasiswa PGSD sudah dikatakan valid dari segi isi, bahasa, kegrafikaan. Sesuai dengan hasil validasi oleh validator ahli bahwa bahan ajar yang dikembangkan telah valid dan dapat digunakan dalam proses pembelajaran. 2) Tanggapan mahasiswa terhadap bahan ajar klasifikasi materi terintegrasi matematika berbasis masalah untuk mahasiswa PGSD berkaitan dengan praktikalitas yaitu kemudahan penggunaan bahan ajar oleh mahasiswa dan tanggapan dosen atau pengajar dalam menggunakan bahan ajar serta keterlaksanaan SAP. Praktikalitas bahan ajar sains terintegrasi matematika berbasis masalah untuk mahasiswa PGSD secara keseluruhan berada kategori sangat praktis. 3) Pencapaian keterampilan berpikir kritis mahasiswa merupakan efektivitas setelah menggunakan bahan ajar. Efektivitas bahan ajar klasifikasi materi terintegrasi matematika berbasis masalah untuk mahasiswa PGSD telah teruji dalam penggunaannya. Berdasarkan pada tahap uji coba dan implementasi pada proses keterampilan berpikir kritis mahasiswa dengan kategori sangat tinggi, aktifitas berpikir kritis mahasiswa selama pembelajaran dengan kategori sangat tinggi, dan peningkatan keterampilan berpikir kritis melalui pre test dan post test menunjukkan hasil yang sedang. Hasil tahap uji coba mengungkapkan pengamatan aktivitas mahasiswa dalam kategori tinggi (80\%) dan hasil tes kemampuan berpikir mahasiswa dengan rata- rata $(88,8)$ dengan kategori sangat baik dengan persentase melebihi batas ketuntasan minimal. Selain itu, hasil tahap implementasi mengungkapkan pengamatan aktivitas mahasiswa dalam kategori sangat tinggi (82\%) dan hasil tes kemampuan berpikir mahasiswa dengan rata- rata $(88,5)$ dengan persentase melebihi batas ketuntasan minimal. 
1764 Pengembangan Bahan Ajar Klasifikasi Materi Terintegrasi Matematika Berbasis Masalah untuk Meningkatkan Kemampuan Berfikir Kritis Mahasiswa PGSD- Indriani Sefti Annisa, Yanti Fitria DOI : https://doi.org/10.31004/basicedu.v5i4.1019

\section{DAFTAR PUSTAKA}

Aldoobie, N. (2015). ADDIE Model. American International Journal of Contemporary Research ADDIE, $5(6), 68-72$.

Arikunto, S. (2010). Prosedur Penelitian Suatu Pendekatan Praktik. Jakarta: Rineka Cipta.

Branch, R. M. (2010). Instructional design: The ADDIE approach. In Instructional Design: The ADDIE Approach. Springer SciencepBusiness Media, LLC, 233 Spring Street, New York, NY 10013, USA. https://doi.org/10.1007/978-0-387-09506-6

Dousay, T. A., \& Logan, R. (2011). Analyzing and evaluating the phases of ADDIE. Proceedings from Design, Development and Research Conference 2011, 32-43.

Evi, T., \& Indarini, E. (2021). Meta Analisis Efektivitas Model Problem Based Learning dan Problem Solving Terhadap Kemampuan Berpikir Kritis Mata Pelajaran Matematika Siswa Sekolah Dasar. Edukatif: Jurnal Ilmu Pendidikan, 3(2), 385-395. https://doi.org/10.31004/edukatif.v3i2.314

Fitria, Y., Helsa, Y., \& Hasanah, F. N. (2019). The learning tool for electric circuit and mathematics logic integration. Journal of Physics: Conference Series, 1321(3). https://doi.org/10.1088/1742$6596 / 1321 / 3 / 032108$

Fitria, Y., Helsa, Y., Nirwana, H., \& Zulkarnaini, A. P. (2018). The integration of science and math. Journal of Physics: Conference Series, 1088. https://doi.org/10.1088/1742-6596/1088/1/012041

Fitria, Yanti. (2014). Refleksi Pemetaan Pemahaman Calon Guru SD Tentang Integrated Sains Learning. Pedagogi, XIV(2), 82-87.

Fitria, Yanti. (2019). Mampukah Model Problem Based Learning meningkatkan Prestasi Belajar Sains Mahasiswa Calon Guru Sekolah Dasar? Jurnal Inovasi Pendidikan Dan Pembelajaran Sekolah Dasar, 3(1), 83. https://doi.org/10.24036/jippsd.v3i1.106372

Fitria, Yanti, Hasanah, F. N., \& Gistituati, N. (2018). Critical Thinking Skills of Prospective Elementary School Teachers in Integrated Science-Mathematics Lectures. Journal of Education and Learning (EduLearn), 12(4), 597-603. https://doi.org/10.11591/edulearn.v12i4.9633

Hamdani. (2011). Strategi Belajar Mengajar. Bandung: Pustaka Setia.

Kiray, S. A. (2011). A new model for the integration of science and mathematics: The balance model. Energy Education Science and Technology PArt B: Social and Educationa; Studies, 4(August), 1181-1196.

Kurinasih, I. d. (2014). Sukses Mengimplementasikan Kurikulum 2013. Surabaya: Kata Pena.

Kurt, K., \& Pehlivan, M. (2013). Integrated Programs for Science and Mathematics: Review of Related Literature. Online Submission, 1(2), 116-121. https://doi.org/10.18404/ijemst.74055

Pendidikan, K. (2016). Implementasi Kurikulum 2013 Sd Mi. Jurnal Inovasi Pendidikan, 1(3).

Pranaja, A., \& Astuti, Y. (2019). Edukatif: Jurnal Ilmu Pendidikan. Jurnal Ilmu Pendidikan, 1(3), 294-302. https://edukatif.org/index.php/edukatif/index

Prastowo, A. (2013). Pengembangan Bahan Ajar Tematik. Yogyakarta: Diva Press.

Ríordáin, M. N., Johnston, J., \& Walshe, G. (2016). Making mathematics and science integration happen: key aspects of practice. International Journal of Mathematical Education in Science and Technology, 47(2), 233-255. https://doi.org/10.1080/0020739X.2015.1078001

Stohlmann, M., Moore, T., \& Roehrig, G. (2012). Considerations for Teaching Integrated STEM Education. Journal of Pre-College Engineering Education Research, 2(1), 28-34. https://doi.org/10.5703/1288284314653

Sugiyono. (2012). Metode Penelitian Pendidikan. Bandung: Alfabeta.

Sumarni, W. (2013). The Strengths and Weaknesses of the Implementation of Project Based Learning: A 
1765 Pengembangan Bahan Ajar Klasifikasi Materi Terintegrasi Matematika Berbasis Masalah untuk Meningkatkan Kemampuan Berfikir Kritis Mahasiswa PGSD-Indriani Sefti Annisa, Yanti Fitria

DOI : https://doi.org/10.31004/basicedu.v5i4.1019

Review. International Journal of Science and Research (IJSR), 4(3), 79-104. https://doi.org/10.1007/978-3-319-95258-1_5

Thibaut, L., Knipprath, H., Dehaene, W., \& Depaepe, F. (2019). Teachers' Attitudes Toward Teaching Integrated STEM: the Impact of Personal Background Characteristics and School Context. International Journal of Science and Mathematics Education, 17(5), 987-1007. https://doi.org/10.1007/s10763-0189898-7

Treacy, P., \& Donoghue, J. O. (2014). Authentic Integration : a model for integrating mathematics and science in the classroom. International Journal of Mathematical Education in Science and Technology, 45(5), 703-718. https://doi.org/10.1080/0020739X.2013.868543

Zuryanty, Kenedi, A. K., Chandra, R., Hamimah, \& Fitria, Y. (2019). Problem based learning: A way to improve critical thinking ability of elementary school students on science learning. Journal of Physics: Conference Series, 1424(1). https://doi.org/10.1088/1742-6596/1424/1/012037 